\title{
Indirect Spectrophotometric Methods for the Determination of Cefadroxil in its Pure and Pharmaceutical Preparations
}

\author{
Nabeel S. Othman \\ Department of Chemistry \\ College of Science \\ University of Mosul
}

Mohanad M. Sehree

\author{
Shielan A. Omer \\ Department of Pharmacy \\ Medical Technical Institute \\ Erbil
}

(Received 27 / 6/2013 ; Accepted 16/12 / 2013)

\begin{abstract}
Two spectrophotometric methods were described for the determination of cefadroxil in pure form and in its pharmaceutical preparations. They were based on the oxidation-reduction reaction between iron (III) and cefadroxil, the liberated $\mathrm{Fe}^{+2}$ is then reacted with 1,10-phenathroline (method I) or 2,2 -bipyridyl (method II) in acidic medium, the colored(red) complexes absorbed at 510 and $521 \mathrm{~nm}$, respectively. Applying the optimum working conditions, cefadroxil can be determined over the concentration range of $0.5-5$ and $0.5-6 \mu \mathrm{g} \cdot \mathrm{ml}^{-1}$ with molar absorptivities of $1.141 \times 10^{5}$ and $6.308 \times 10^{4} 1 . \mathrm{mol}^{-1} . \mathrm{cm}^{-1}$ for method I and method II, respectively. The proposed methods were applied successfully to the determination of cefadroxil in various pharmaceutical preparations.
\end{abstract}

Keywords: cefadroxil,oxidation-reduction, 1,10-phenathroline, 2,2'-bipyridyl, spectrophotometry.
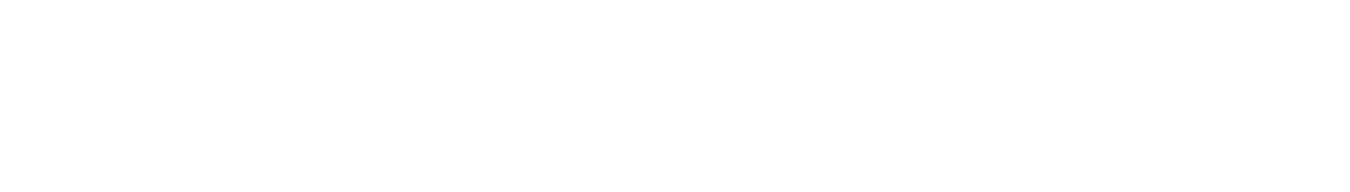

يشل البحث وصف طريقتن طيفيتن غير مبلثرتين لقدير الميفادروكسل شكله الحر وفي مستحضراته الصيدلانيه. تتضصن الطريقتلن لختزل ايون الحديد الثلاثي بوسطلة للسيفادروكسيل ومن مُ مفاعلة الحديد الثنائي الناتج مع الكلثفين 10,1 فيناثرولين (طريقة 1) و2,2 - باي برينل (طريقة 2) في الوسط الحلمضي لتكوين معقين ملونين كلن الامتصاص الأغظم لهما

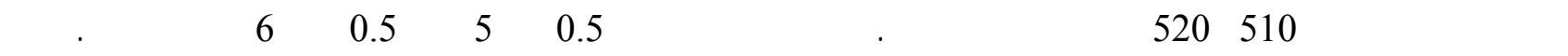

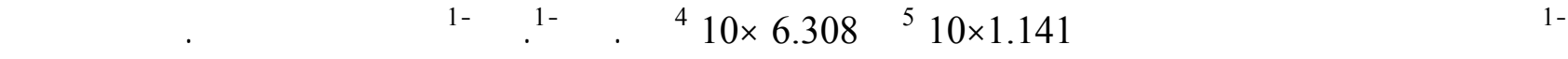
الطريقتن بنجاح في تقدير للسيفادروكسل في مستحضراته الصيدلانيه.

الهاملت الدالة :سيفادروكسيل، لٔكسة ولختزل، 10,1 -فيناثرولين، 2,2- - باي بريبل،طيفي.

\section{INTRODUCTION}

Cefadroxil, an orally active cephalosporin in clinical practice, which belongs to the group of lactam antibiotics 1 . It is chemically designated as 5-thia-1-azabicyclo[4.2.0]oct-2-ene-2-carboxylic acid, 7-[[amino(4-hydroxyphenyl) acetyl]-amino]-3-methyl-8-oxo-, monohydrate. Its antibacterial activity was dependent on the presence of the $\beta$-lactam functionality that can be hydrolyzed (American Pharmaceutical Association, 1990). It has the following chemical structure (British Pharmacopeia, 2000): 


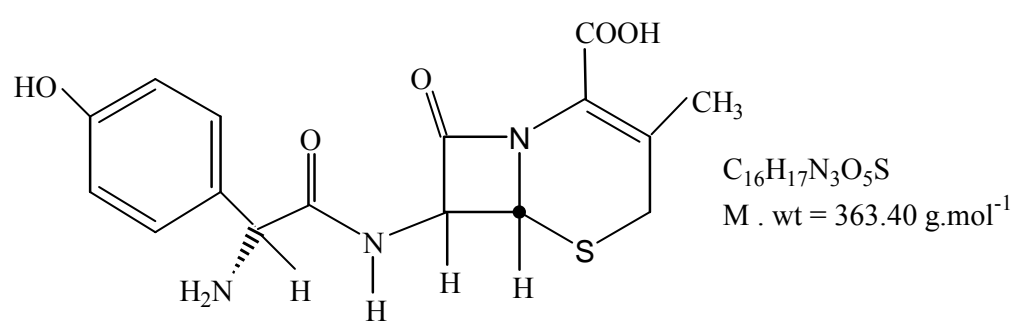

\section{Cefadroxil}

A variety of techniques have been used for the determination of cefadroxil: Chromatography (Ting, 1988; Manna and Valvo, 2004; Ravi et al., 2008; Karageorgou and Samanidou, 2010), flow injection (Awni et al., 1999; Thongpoon et al., 2006), and fluorometry (Yang et al., 1998; El-Walily et al., 1999). Also, various spectrophotometric methods have been used in the determination of cefadroxil in pure form and in its pharmaceuitical preparations used for various reagents such as diazotised benzocaine in the presence of triethylamine (El-Ashry et al., 2000), diazotised $p$-nitroaniline (Othman et al., 2006), 4-aminoantipyrine in the presence of an alkaline oxidizing agent (Aly et al.,1994), 3-methyl-2-benzothiazolinone hydrazone hydrochloride in the presence of ceric ammonium sulphate, 4-aminophenazone in the presence of potassium hexacyanoferrate (III), 2,6-dichloroquinone-4-chlorimide (Sastry et al.,1997), Cu(II) and V(V) in sulphuric acid (Badawy et al., 1993), Folin-Ciocalteu reagent in presence of sodium hydroxide and stannous chloride (Prasad et al., 2004), 2,3-dichloro-5,6-dicyano-1,4-benzoquinine (Al-Ghabsha et al., 2007), molybdophosphoric acid as an oxidising agent (Issopoulos, 1989), Ce (IV) or Fe (III) (Salem and Saleh, 2002), bromated- bromide mixture in acidic medium (Mallapu et al., 2011) 1, 2naphthaquinone-4-sulphonic acid sodium in alkaline medium (Kumar et al., 2011), variamine (Pasha and Narayana, 2008), quercetin (Gamal et al., 2009) after nitration and subsequent complexation with a nucleophilic reagent, nitrosation and subsequent metal chelation, coupling with diazo reagent, reaction with copper and extraction of the resulting chelate into chloroform (Salem, 2004), sodium hydroxide (Shantier, 2011) and 4-chloro-7-nitrobenzo-2-oxa-1,3-diazole (Azza et al., 2010).

However some of the above methods suffer from several disadvantage such as the extraction of the resulting dye into non- aqueous solvent (Salem, 2004).

The objective of the investigation reported in this paper is to evaluate simple spectrophotometric methods for the determination of cefadroxil, the methods are based on the oxidation of cefadroxil with ferric ions in acidic medium and subsequent complexation of ferrous ions with 1,10-phenathroline (method I) or with 2,2 -bipyridyl (method II). The resulting colored complexes formed prove to be intense, water- soluble and stable.

\section{EXPERIMENTAL}

\section{Apparatus}

The spectrophotometric measurements were carried out on Shimadzu UV-Visible Spectrophotometer UV-160 and Shimadzu (1650 PC) UV-Visible Spectrophotometer, using 1-cm quartz cells.

\section{Reagents and solutions}

All chemicals used are of an analytical grade. Cefadroxil was purchased from the State Company for Drug Industries and Medical Applicanes (SDI), Sammara, Iraq.

Cefadroxil solution, $50 \mu \mathrm{g} . \mathrm{ml}^{-1}$, was prepared by dissolving $0.0100 \mathrm{~g}$ of cefadroxcil in $200 \mathrm{ml}$ distilled water in a volumetric flask. 
1,10-Phenathroline and 2,2 -bipyridyl solutions $\left(2 \times 10^{-2} \mathrm{M}\right)$ were prepared by dissolving $0.087 \mathrm{~g}(1,10$-phenathroline monohydrate) and $0.078 \mathrm{~g}$ for each reagent respectively in $5 \mathrm{ml}$ absolute ethanol and the volume completed to $25 \mathrm{ml}$ with distilled water in a volumetric flask.

Oxidant reagent $\left(\mathrm{Fe}^{+3}, 0.02 \times 10^{-2} \mathrm{M}\right)$ solution was prepared by dissolving $0.2 \mathrm{~g}$ of ferric nitrate nanohydrate (Fluka) in $5 \mathrm{ml}$ nitric acid (1M), then the volume was completed to $25 \mathrm{ml}$ with distilled water in a volumetric flask.

Other solutions needed were prepared by dissolving the appropriate amount in distilled water.

\section{General procedures \\ Method I:}

Aqueous solution containing cefadroxil in the range 5-50 $\mu \mathrm{g}$ was transferred into $10 \mathrm{ml}$ volumetric flasks, then $0.3 \mathrm{ml}$ of $2 \times 10^{-2} \mathrm{M}$ of ferric solution was added followed by the addition of 3 $\mathrm{ml}$ of $2 \times 10^{-2} \mathrm{M}$ of 1,10-phenathroline solution. Finally, the volumes were completed to $10 \mathrm{ml}$ with distilled water and heated on a water- bath adjusted at $80^{\circ} \mathrm{C}$ for 40 minutes. The absorbance was measured at $510 \mathrm{~nm}$ against a reagent blank.

\section{Method II:}

A portion of solution containing cefadroxil in the range 5-60 $\mu \mathrm{g}$ was transferred into $10 \mathrm{ml}$ volumetric flasks containing $1.6 \mathrm{ml}$ of $2,2^{\prime}$-bipyridyl $\left(2 \times 10^{-2} \mathrm{M}\right)$, followed by the addition of $0.1 \mathrm{ml}$ of $\mathrm{Fe}^{+3}$ solution $\left(2 \times 10^{-2} \mathrm{M}\right)$. Finally, the volumes were completed to $10 \mathrm{ml}$ with distilled water. The solutions were heated on a water bath adjusted at $80^{\circ} \mathrm{C}$ for 50 minutes. The absorbance was measured at $521 \mathrm{~nm}$ against a reagent blank.

\section{Determination of cefadroxil in pharmaceutical preparations}

Tablets: Ten tablets [cefadroxil (500 mg/tablet), Ajanta Pharma Limited, (India)] were weighted accurately and powdered in a mortar. An amount corresponding to $50 \mathrm{mg}$ of cefadroxil was dissolved in warm distilled water, and filtered then the volume of the filtrate was completed to $50 \mathrm{ml}$ with distilled water in a volumetric flask. An appropriate aliquots were taken and the recommended procedures were followed for the spectrophotometric determination of cefadroxil.

\section{Determination of cefadroxil in suspension:}

An accurate weight of the content of the container [cefadroxil oral suspension syrup $(250 \mathrm{mg} / 5 \mathrm{ml})$, (Syria)] equivalent to $0.0100 \mathrm{~g}$ of pure cefadroxil was dissolved in a mixture of $2 \mathrm{ml}$ hydrochloric acid $(0.1 \mathrm{M})$ and $3 \mathrm{ml}$ of absolute ethanol, then $25 \mathrm{ml}$ of warm distilled water was added, after filtration the volume was completed to $100 \mathrm{ml}$ with distilled water in a volumetric flask. An appropriate aliquot was taken and the recommended procedures were followed for analysis of the drug.

\section{Determination of cefadroxil in capsule:}

Content of 5 capsules [cefadroxil capsules (500 mg/ capsule), Bristol-Myerssquibb (Egypt)] was calculated. An accurately weighed amount of the powdered sample equivalent to $0.0100 \mathrm{~g}$ cefadroxil was dissolved in warm distilled water, then the volume completed to $100 \mathrm{ml}$ in a volumetric flask with distilled water. An appropriate aliquot was taken and the recommended procedures were followed for the spectrophotometric determination of cefadroxil.

\section{RESULTS AND DISCUSSION}

The proposed methods were based on the ability of cefadroxil to reduce $\mathrm{Fe}^{+3}$ to $\mathrm{Fe}^{+2}$ which is rapidly reacted in the presence of 1,10-phenathroline (method I) or 2,2'-bipyridyl (method II) to highly stable colored complexes, which absorb at $510 \mathrm{~nm}$ and $521 \mathrm{~nm}$, respectively. To find the optimum analytical conditions for the determination of cefadroxil, the effect of various variables on the color development was tested.

\section{Effect of pH}

The effect of $\mathrm{pH}$ on the absorbance of formed colored products was studied using different amounts of various types of acids $\left(\mathrm{HCl}, \mathrm{HNO}_{3}, \mathrm{H}_{2} \mathrm{SO}_{4}\right.$ and $\left.\mathrm{CH}_{3} \mathrm{COOH}\right)$ and sodium hydroxide. The 
obtained results showed that the maximum color intensity was attained by mixing the components of the two reactions ( $\mathrm{pH} 2.9$ for method I and 3.0 for method II). Different buffer solutions with $\mathrm{pH} 3$ [KHphthalate $+\mathrm{HCl}(\mathrm{B} 1)$, Tartaric acid $+\mathrm{NaOH}(\mathrm{B} 2)$ and citric acid $+\mathrm{NaOH}(\mathrm{B} 3)$ ] were used. The results showed that all buffer solutions used decreased the absorbance of formed colored products, so that the subsequent experiments go on mixing the components of the two reactions in the absence of buffer solution.

\section{Effect of $\mathrm{Fe}^{+3}$ solution concentration}

The effect of $\mathrm{Fe}^{+3}$ solution concentration on the absorbance of both methods was studied. It was found that keeping cefadroxil and 1,10-phenathroline or 2,2'-bipyridyl at a constant concentration and increasing the concentration of iron (III) resulted in an increase in the absorbance up to $0.3 \mathrm{ml}$ and $0.2 \mathrm{ml}$ of $2 \times 10^{-2} \mathrm{M}$ ferric solution, respectively (Table 1 ).

Table 1: The effect of ferric solution amount on absorbance

\begin{tabular}{|l|l|l|l|l|}
\hline $\begin{array}{c}\text { ml of ferric solution } \\
\left(\mathbf{2} \times \mathbf{1 0}^{-2} \mathbf{M}\right)\end{array}$ & $\mathbf{0 . 1}$ & $\mathbf{0 . 2}$ & $\mathbf{0 . 3}$ & $\mathbf{0 . 4}$ \\
\hline $\mathrm{A}_{\mathrm{I}}$ (method I) & 0.231 & 0.538 & 0.763 & 0.667 \\
\hline $\mathrm{A}_{\mathrm{II}}$ (method II) & 0.223 & 0.410 & 0.231 & 0.180 \\
\hline
\end{tabular}

\section{Effect of reagents amount}

The effect of the amount of 1,10-phenathroline (method I) or 2,2'-bipyridyl (method II) was studied. A $1.2 \mathrm{ml}$ (method I) and $1.6 \mathrm{ml}$ (method II) of $2 \times 10^{-2} \mathrm{M}$ of each reagent mentioned above (Table 2) were recommended as an optimal value for the subsequent experiments because of their high sensitivity.

Table 2: The effect of reagent amount on absorbance

\begin{tabular}{|c|c|c|c|c|c|c|}
\hline \multirow{2}{*}{$\begin{array}{l}\text { Reagent } \\
\text { amount } \\
\text { (ml) }\end{array}$} & \multicolumn{6}{|c|}{ Absorbance / $\mu$ g cephadroxile $/ 10 \mathrm{ml}$} \\
\hline & & 12.5 & 25 & 37.5 & 50 & $\mathrm{r}^{2}$ \\
\hline \multirow[b]{2}{*}{1.0} & $\mathrm{~A}_{\mathrm{I}}($ Method I $)$ & 0.312 & 0.748 & 0.990 & 1.320 & 0.987 \\
\hline & $\mathrm{A}_{\mathrm{II}}($ Method II $)$ & 0.189 & 0.320 & 0.482 & 0.523 & 0.955 \\
\hline \multirow[b]{2}{*}{1.2} & $\mathrm{~A}_{\mathrm{I}}($ Method I $)$ & 0.412 & 0.890 & 1.038 & 1.380 & 0.962 \\
\hline & $\mathrm{A}_{\mathrm{II}}($ Method II $)$ & 0.219 & 0.411 & 0.552 & 0.669 & 0.987 \\
\hline \multirow[b]{2}{*}{1.6} & $\mathrm{~A}_{\mathrm{I}}($ Method I $)$ & 0.381 & 0.730 & 0.909 & 1.287 & 0.910 \\
\hline & $\mathrm{A}_{\text {II }}($ Method II $)$ & 0.270 & 0.525 & 0.686 & 0.880 & 0.991 \\
\hline \multirow[b]{2}{*}{2.0} & $\mathrm{~A}_{\mathrm{I}}($ Method I $)$ & 0.391 & 0.689 & 0.789 & 1.203 & 0.951 \\
\hline & $\mathrm{A}_{\text {II }}($ Method II $)$ & 0.225 & 0.408 & 0.544 & 0.621 & 0.968 \\
\hline
\end{tabular}

\section{Effect of temperature}

The effect of temperature on the intensity of product complexes was studied in the range 25$90^{\circ} \mathrm{C}$. The obtained results showed that maximum absorbance occurs at $80^{\circ} \mathrm{C}$ in the two methods (Table 3). 
Table 3: Effect of temperature on absorbance

\begin{tabular}{|c|l|l|l|l|l|l|}
\hline $\mathrm{T},{ }^{\circ} \mathrm{C}$ & 25 & 50 & 60 & 70 & 80 & 90 \\
\hline $\mathrm{A}_{\mathrm{I}}($ Method I $)$ & 0.077 & 0.329 & 0.701 & 1.187 & 1.325 & 1.223 \\
\hline $\mathrm{A}_{\text {II }}$ (Method II) & 0.080 & 0.322 & 0.348 & 0.758 & 0.945 & 0.804 \\
\hline
\end{tabular}

\section{Effect of time on reduction}

The effect of time needed for the complete reduction of $\mathrm{Fe}^{+3}$ to $\mathrm{Fe}^{+2}$ was studied. The obtained results showed that method I needs 40 minutes while method II needs 50 minutes for a complete oxidation-reduction and chelation reactions at temperature $80{ }^{\circ} \mathrm{C}$ (Table 4).

Table 4: Effect of reduction time

\begin{tabular}{|c|c|c|c|c|c|c|c|}
\hline & \multicolumn{7}{|c|}{ Absorbance /Minute } \\
\hline & 5 & 10 & 20 & 30 & 40 & 50 & 60 \\
\hline $\mathrm{A}_{\mathrm{I}}$ (Method I) & 0.563 & 0.678 & 0.974 & 1.331 & 1.386 & 1.301 & 1.280 \\
\hline $\mathrm{A}_{\mathrm{II}}$ (Method II) & 0.465 & 0.713 & 0.803 & 0856 & 0.880 & 0.952 & 0.897 \\
\hline
\end{tabular}

\section{Effect of order of addition}

The effect of the order of addition was studied by preparing solutions with different addition orders. The results showed that the orders fixed in the recommended procedures give a high intensity of the complexes.

\section{Effect of interference}

The effect of some excipients usually present in the pharmaceutical preparation were investigated by carrying out the determination of $50 \mu \mathrm{g}$ cefadroxil in the presence of different excipients (glucose, starch, gum Arabic and lactose). Experimental results showed that there was no interference from excipients for the experimental methods up to 20 fold excess except glucose at high amount ratio.

\section{Absorptions spectra}

When cefadroxil in aqueous solution was treated with 1,10-phenathroline (method I) or 2,2'bipyridyl (method II) reagents in the presence of $\mathrm{Fe}^{+3}$, absorption peaks were obtained showing intense absorptions at $510 \mathrm{~nm}$ (method I) and $520 \mathrm{~nm}$ (method II). The above wavelengths of maximum absorption have been used in all subsequent experiments Fig. (1 and 2). 


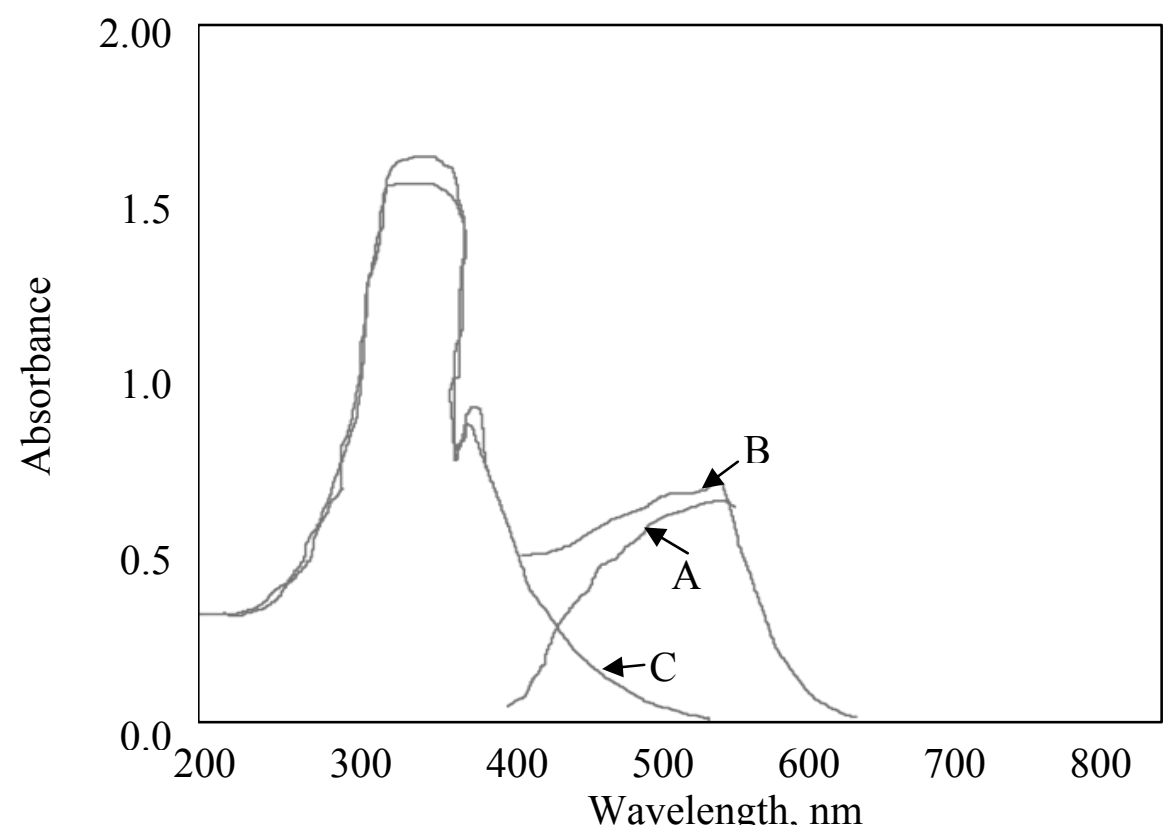

Fig. 1: Absorption spectra of $25 \mu \mathrm{g}$ cefadroxil (method I) and treated according to the recommended procedures and measured against (A) blank (B) distilled water and (C) blank measured against distilled water.

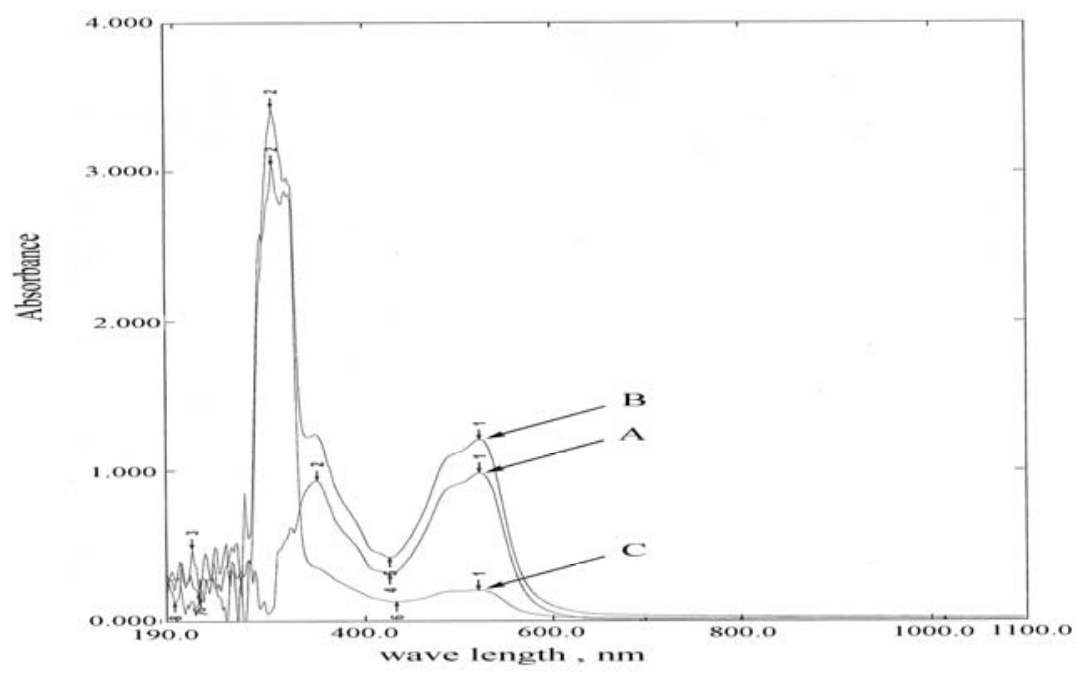

Fig. 2: Absorption spectra of $50 \mu$ g cefadroxil (method II ) and treated according to the recommended procedures and measured against (A) blank (B) distilled water and (C) blank measured against distilled water.

\section{Calibration curves}

Following the general procedures, linear relationships were obtained between the absorbance and the concentration of cefadroxil within the range 5-50 $\mu \mathrm{g} / 10 \mathrm{ml}(0.5-5 \mathrm{ppm})$ in method I and 5-60 $\mu \mathrm{g} / 10 \mathrm{ml}(0.5-6 \mathrm{ppm})$ in method II. Fig. (2). The sensitivity of the methods for the determination of cefadroxil expressed in terms of molar absorpitivity were $1.141 \times 10^{5}$ and $6.308 \times 10^{4} 1 . \mathrm{mol}^{-1} . \mathrm{cm}^{-1}$ for method I and II, respectively. 


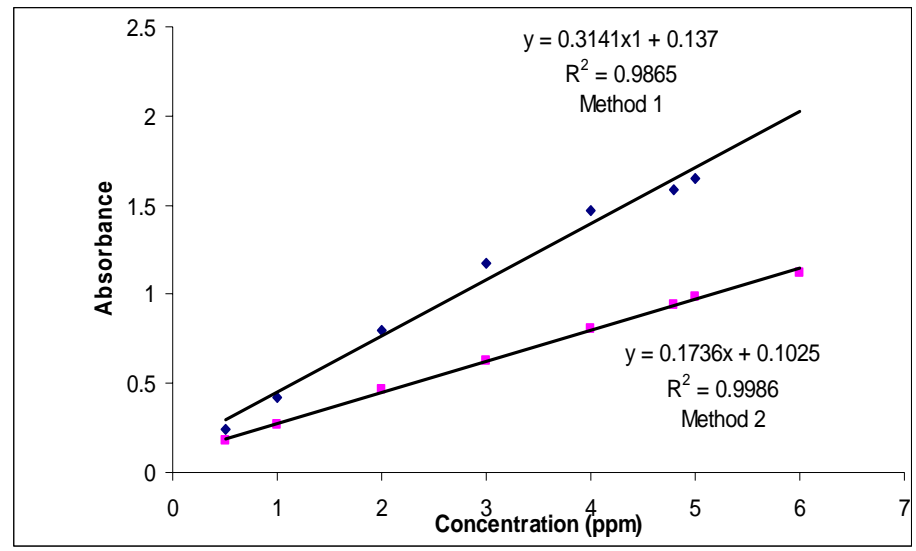

Fig. 2: Calibration graphs of cefadroxil determination

The accuracy and precision were checked by five successive measurements of $25 \mu \mathrm{g}$ of cefadroxil expressed as the relative error and relative standard deviations (Table 5).

Table 5: The accuracy and precision

\begin{tabular}{|l|c|c|c|}
\hline \multirow{2}{*}{ Method I } & $\mu \mathrm{g}$ cefadroxil/10ml & Relative error, \%* & RSD , \%* \\
\hline \multirow{3}{*}{ Method II } & 25 & -0.41 & 0.812 \\
\cline { 2 - 4 } & 50 & +0.870 & 1.341 \\
\cline { 2 - 4 } & 25 & +0.158 & 1.183 \\
\hline
\end{tabular}

*Average of five determinations.

The results illustrated in Table 5 indicated that they were satisfactory.

\section{Stoichiometry of the complexes}

The ferrous ion produced from the reaction between ferric ion and cefadroxil is chelated by 2,2'-bipyridyl or 1,10-phenathroline to form the well-known complexes $\left[1 \mathrm{Fe}^{+2}: 3\left(2,2^{\prime} \text {-bipyridyl }\right)\right]^{+2}$ and $\left[1 \mathrm{Fe}^{+2}: 3(1,10-\text { phenathroline) }]^{+2}\right.$, respectively (scheme 1) (Foster,1978; Christian,1986).

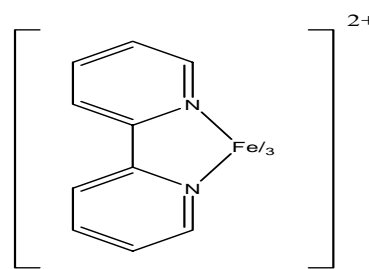

Red complex

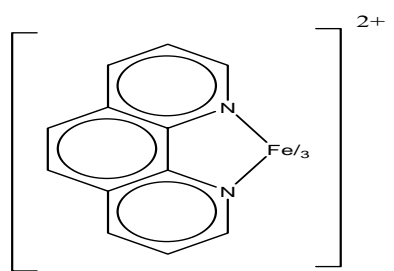

Red- orange complex

Scheme 1 .Stoichiometry of complexes.

The stability constants (Hargis, 1988) of the formed complexes were $1.679 \times 10^{11} \mathrm{~L}^{3} \cdot \mathrm{Mol}^{-3}$ $6.22 \times 10^{14} \mathrm{~L}^{3} \cdot \mathrm{Mol}^{-3}$ method I and method II respectively. 


\section{Determination of cefadroxil in a pharmaceutical formulations}

The validity of the proposed methods for spectrophotometric determination of cefadroxil was checked by the analysis of cefadroxil in different pharmaceutical preparations. The results obtained were given in (Table 6) which confirm the applicability of the methods.

Table 6: The results of application part

\begin{tabular}{|l|c|c|c|}
\hline & \multicolumn{3}{|c|}{ Recovery*, \% } \\
\hline & $\mu \mathrm{g}$ cefadroxil/10ml & Method I & Method II \\
\hline Cephadroxil tablets & & & \\
\hline ( 500mg/tablet) Ajanta & 25 & 98.80 & 97.00 \\
\hline Pharma Limited (India) & 50 & 99.40 & 104.12 \\
\hline Cephadroxil capsules & & & 100.50 \\
\hline ( 500mg/capsule) & 25 & 99.30 & 101.30 \\
\hline Bristol-Myerssquibb (Egypt) & 50 & 98.78 & 99.64 \\
\hline Cephadroxil oral suspenstion & & & 102.00 \\
\hline syrup (250mg/5ml) & 25 & 98.90 & \\
\hline pharmaceutical (Syria) & 50 & 97.40 & \\
\hline
\end{tabular}

*Average of five determinations

\section{Comparison of the methods}

Table (7) shows a comparison between some of the analytical variables for the present methods with that of other literature spectrophotometric methods.

Table 7: Comparison of the methods

\begin{tabular}{|c|c|c|c|c|}
\hline $\begin{array}{l}\text { Analytical } \\
\text { parameters }\end{array}$ & Method I & Method II & $\begin{array}{c}\text { Literature } \\
\text { method }^{*}\end{array}$ & Literature method $^{* *}$ \\
\hline $\mathrm{pH}$ range & $2.9-3.1$ & $2.9-3.2$ & $\ldots$ & $\ldots$ \\
\hline $\begin{array}{l}\text { Temperature } \\
\left(\mathrm{C}^{\circ}\right)\end{array}$ & 80 & 80 & $\begin{array}{c}\text { Room } \\
\text { temperature }\end{array}$ & Room temperature \\
\hline$\lambda \max (\mathrm{nm})$ & 510 & 521 & 479 & 500 \\
\hline $\begin{array}{l}\text { Medium of } \\
\text { reaction }\end{array}$ & Aqueous & Aqueous & Aqueous & Aqueous \\
\hline Type of reaction & $\begin{array}{l}\text { Oxidation - } \\
\text { reduction }\end{array}$ & $\begin{array}{l}\text { Oxidation - } \\
\text { reduction }\end{array}$ & Diazo coupling & Oxidative coupling \\
\hline Reagent & $\begin{array}{c}1,10- \\
\text { phenathroline }\end{array}$ & 2,2’-bipyridyl & $\begin{array}{c}\text { Diazotised } \\
p \text {-nitroaniline }\end{array}$ & $\begin{array}{l}\text { 4-Amino- antipyrine } \\
\text { with potassium } \\
\text { hexacyano- pherrate }\end{array}$ \\
\hline $\begin{array}{l}\text { Beer's law range } \\
\quad(\mathrm{ppm})\end{array}$ & $0.5-5$ & $0.5-6$ & $0.4-8$ & $1-28$ \\
\hline $\begin{array}{l}\text { Molar } \\
\text { absorptivity } \\
\left(1 . \mathrm{mol}^{-1} \cdot \mathrm{cm}^{-1}\right)\end{array}$ & $1.141 \times 10^{5}$ & $6.308 \times 10^{4}$ & $2.22 \times 10^{4}$ & $1.30 \times 10^{4}$ \\
\hline $\begin{array}{l}\text { Colour of the } \\
\text { dye }\end{array}$ & Red & Red & Orange & Red \\
\hline $\begin{array}{l}\text { Application of } \\
\text { the method }\end{array}$ & $\begin{array}{l}\text { Tablets, capsules } \\
\text { and suspensions }\end{array}$ & $\begin{array}{l}\text { Tablets, capsules } \\
\text { and suspensions }\end{array}$ & $\begin{array}{l}\text { Tablets and } \\
\text { suspensions }\end{array}$ & $\begin{array}{l}\text { Capsules and } \\
\text { suspensions }\end{array}$ \\
\hline
\end{tabular}

* Othman et al., 2006.

** Aly et al., 1994.

\section{CONCLUSION}

The comparison between different methods for the determination of cefadroxil (Table 7) indicates that the two proposed methods have a reasonable sensitivity with molar absorpitivities $1.117 \times 10^{5} 1 . \mathrm{mol}^{-1} \cdot \mathrm{cm}^{-1}$ (method I) $6.177 \times 10^{4} 1 . \mathrm{mol}^{-1} \cdot \mathrm{cm}^{-1}$ (method II), which indicate that method (I) is the more sensitive method. On the other hand, the two proposed methods can be successfully used for the determination of cefadroxil in pharmaceutical preparations. 


\section{REFERENCES}

Al-Ghabsha, T.S.; Al-Sabha, T.N.; Al-Mtaiwti, S.M. (2007). Spectrophotometric determination of cephradine and cephadroxil using 2,3-dichloro-5,6-dicyano-1,4- benzo quinine reagent . J. Pure Appl. Sci., 4(3), 13-28.

Aly, F.A.; Walash, M.I.; Belal, F. (1994). Spectrophotometric determination of cephadroxil and metyrosine in dosage forms. Anal. Lett., 27(14), 2677-2687.

American Pharmaceutical Association; The United States Pharmacopeia, XXII, Washington, 1990.

Awni, F.; IKhalil, H.S.; Esmadi, F. (1999). Spectrophotometric determination of cefadroxil in drug formulations using flow injection analysis. Anal. Lett., 32(15), 2977-2988.

Azza, H.R.; El-Shaboury, S.R.; Saleh, G.A.; Fardous, A.M. (2010). Spectophotometric method for determination of certain cephalosporins using 4-chloro-7-nitrobenzo-2-oxa-1,3-diazole (NBD-Cl) . Natural Science, 2(8), 828-840.

Badawy, S.S.; Abdel-Gawad, F.M.; Ibrahim, M.M. (1993). Spectrophotometric studies on determination of cephadroxil with copper(II) and vanadium(V) in sulphuric acid medium. Anal. Lett., 26(3), 487-497.

"British Pharmacopeia on CD-Rom", (2000). 3rd edn., System Simulation Ltd., the Stationary Office, London.

Christian, G.D. (1986). “Analytical Chemistry". 4th ed., John Wiley and Sons, New Yorkp. 598 p.

El-Ashry, S.M.; El-Kerdawy, M.M.; Wassef, D.R.E. (2000). Spectrophotometric determination of some phenolic antibiotics in dosage forms. Mikrochimica. Acta, 135 (3-4), 191-196.

El-Walily, A.F.; Gazy, A.A.; Belal, S.F.; Khamis, E.F. (1999). Selective spectrofluorimetric determination of phenolic beta-lactam antibiotics through the formation of their coumarin derivatives. J. Pharm. Biomed. Anal., 20(4), 643-653.

Foster, D.S. (1978). "Photometric and Fluorometric Methods of Analysis of Metals". part 1, John Wiley and Sons, Inc., New York, 750p.

Gamal, A.S.; El-Shaboury, S.R.; Fardous, A.M.; Azza, H.R. (2009). Kinetic spectrophotometric determination of certain cephalosporins using oxidized quercetin reagent. Spectrochim Acta A Mol. Biomol. Spectrosc.,73(5), 946-54.

Hargis, L.G. (1988). "Analytical Chemistry, Principles and Techniques". Prentice-Hall International, London, pp. 424-427.

Issopoulos, P.B. (1989). Spectrophotometric determination of certain cephalosporins using molybdosphoric acid, part II. Determination of cephadroxil, cephapirin, cephoranide and cephuroxime. Analyst, 114(2), 237-239.

Karageorgou, E.G.; Samanidou, V.F. ( 2010). Application of ultrasound-assisted matrix solid-phase dispersion extraction to the HPLC confirmatory determination of cephalosporin residues in milk. J. Separation Sci., 33(17-18), 2862-2871.

Kumar, C.A.; Gurupadayya, B.; Sloka, S.N.; Chandan, R.; Thejaswini, J. (2011). Colorimetric determination of cefadroxil and ceftriazone in pharmaceutical dosage forms. Tropical J. Pharmaceutical Research, 10(1),81-88.

Mallapu, R.E.; Hindustan, A.A.; Sreenivasulu, R.; Mahendra, K.P.; Akula, A.K., Siddaiah, G. (2011). Spectrophotometric determination of cefadroxil in pharmaceuticals dosage forms by bromination method. J. Pharmacy Research, 4(3), 739-740.

Manna, L.; Valvo L. (2004). Development and validation of a fast reversed-phase ion-pairing liquid chromatographic method for simultaneous determination of eight cephalosporin antibiotics in pharmaceutical formulations. J. Chromatogr., 60(11-12), 645-649.

Othman, N.S.; Mansour, S.S.; Al-Shaheen, Sh. (2006). Spectrophotometric determination of cephadroxil by coupling with diazotised p-nitroaniline - application to pharmaceutical preparations. Tikrit J. Pure Sci., 11(2), 201-203. 
Pasha, C.; Narayana, B. ( 2008). A simple method for the spectrophotometric determination of cephalosporins in pharmaceuticals using variamine blue. Ecl. Quím., São Paulo, 33(2), 41-46.

Prasad M.; Nagaraju, R.; Narayan, T. (2004). Spectrophotometric determination of cephadroxil in dosage forms. Indian J. Pharm. Sci., 66(3), 341- 342.

Ravi, S.S.; Pandey, S.; Rajesh, B.; Asha, P.; Tiwari, M. (2008). Novel HPLC analysis of cefadroxil in bulk formulation. Asian J. Pharmaceutics, 2(2), 106-109.

Salem, H.; Saleh, G.A. (2002). Selective spectrophotometric determination of phenolic beta-lactam antibiotics. J. Pharm. Biomed. Anal., 28(6), 1205-1213.

Salem, H. (2004). Selective spectrophotometric determination of phenolic $\beta$-lactam antibiotics in pure forms and in their pharmaceutical formulations. Anal. Chim. Acta., 515(2), 333-341.

Sastry, C.S.P.; Rao, K.R.; Prasad, D.S. (1997). Determination of cephadroxil by three simple spectrophotometric methods using oxidative coupling reactions. Mikrochim. Acta., 126(12), $167-172$.

Shantier, S.W.; Gadkarier, E.A.; Ibrahim, K.E. (2011). Spectrophotmetric determination of cefadroxil in bulk and dosage form using sodium hydroxide. E- J. Chem., 8(3), 13141322.

Ting, S. (1988). Reverse-phase liquid chromatographic analysis of cephalosporins. J. Assoc. Anal. Chem., 71(6), 1123-1130.

Thongpoon, C.; Liawruangrath, B.; Liawrungrath, S.; Wheatley, R.; Townshend, A. (2006). Flow injection chemiluminescence determination of cephadroxil using potassium permanganate and formaldehyde system. J. Pharm. Biomed. Anal., 42(2), 277-282.

Yang, J.; Zhou, G.; Cao, X.; Dong, J. (1998). Study on the fluorescence characteristics of alkaline degredation of cephadroxil, cephradine, cephotaximum sodium and amoxicillini. Anal. Lett., 31(6), 1047-1060. 